\author{
Kalaman 0. \\ Ph. D., Associate Professor \\ Department of Management and Logistics \\ E-mail: kalaman.olga@gmail.com \\ ORCID ID: 0000-0001-5586-7654
}

Solovey A.

Ph. D., Associate Professor

Department of Sociology, Philosophy and Law

E-mail: solovanatoly@gmail.com

ORCID ID: 0000-0003-0047-0179

\author{
Kananykhina 0. \\ Ph.D., Associate Professor \\ Department of Biochemistry, Microbiology and \\ Physiology nutrition \\ E-mail: k_elni@ukr.net \\ ORCID ID: 0000-0001-6291-7760 \\ Beznis P. \\ Assistant \\ Department of Foreign Languages \\ Odessa National Academy of Food Technologies \\ Kanatna str., 112, Odesa, Ukraine, 65039 \\ E-mail: polina11000@ gmail.com
}

\title{
FORMATION OF LEADERSHIP QUALITIES AND SOCIAL RESPONSIBILITY OF THE MODERN MANAGER IN ODESSA NATIONAL ACADEMY OF FOOD TECHNOLOGIES
}

The relevance of this topic is determined by the need for the formation of students' leadership skills and their personal social responsibility that will allow graduates to master the skills to work in a team, to be an effective manager of enterprise of any level. The article analyzes the prospects for the development of leadership qualities of future managers using paradigm of the organization of this work at the Faculty of Management, Marketing and Logistics of Odessa National Academy of Food Technologies. Such indicators of the development of leadership abilities of future managers as intellectual-creative, organizational, socially communicative and others were used. The analysis showed that students of the Faculty of Management, Marketing and Logistics have sufficiently developed personal qualities necessary for the current leadership. In this regard, indicators characterizing largely the development of leadership qualities, social responsibility, communicative and organizational abilities of students have been considered in the article.

Key words: leadership, leadership potential, students, education, management, social responsibility.

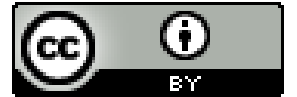

This work is licensed under a Creative Commons Attribution 4.0 International License http://creativecommons.org/licenses/by/4.0/
Statement of the problem and its connection with important scientific and practical tasks. Innovative processes, taking place in Ukraine, and related to changes in public life, socio-economic situation, modernization of education, put forward fundamentally new requirements for the professional training of future specialists. Today, the labor market requires active highprofessional specialists with developed leadership abilities, organizational skills, with non-standard ideas, who can work in a team, to be a leader in it, to form productive relationships with other people, to make social and responsible decisions. Recently, the issues of leadership, social responsibility of personality in political and economic life, in entrepreneurial and scientific activity acquire more and more relevance.

The analysis of the latest publications on the problem. The study of individual aspects of leadership and social responsibility issues to ensure the success of the personality development was reflected in the scientific literature. In particular, the question of the significance of leadership is considered by specialists from management positions (Albert M., Arzhiris K., Khrichevsky M., Mescon M., Khedoury F.), philosophy (Atamanchuk G., Lomachinska I., Krychevsky R.), political science (Deni- syuk S., Kuznetsova S., Lisyuk A., Pakharev A., Shkolyar M.) psychology (Agueyev P., Andreyeva G., Arkin E., Bodalev O., Lutoshkin A., Zherebova N., Paryguin B.), pedagogy (Alphimov D., Makarenko A., Sukhomlynsky V., Shatsky S., Semenchenko N.) [10, p. 244].

The issue of social responsibility is considered in the works of Goguli O. [1], Zateyshchykova O. [2], Zinchenko A. [3], Kovalchuk N. [4], Saprykina M. [9] and other scientists.

At the same time, the scientific literature does not cover entirely the integral study of the experience of practical work at the institutions of higher education on the issue of the formation leadership qualities of future specialists

Forming of the aims of the research. The already mentioned problem is of great importance in social society. The development of leadership qualities, social responsibility of students and complex of measures taken for the formation of the future specialist personality at the institutions of higher education of Ukraine should contribute to the qualitative renovation of the country. However, the effectiveness of some of these measures remains insufficiently studied. The experience of such necessary work at Odessa National Academy of Food Technologies 
is interesting and caused the research direction for the article.

Giving an account of the main results and their substantiation. The state of the world economy in modern conditions is characterized by the activation of a market economy, information development of the society, openness of markets, intensification of the introduction of innovative technologies and expansion of the overall level of production modernization. Such changes require from workers not only of a higher level of professional qualification, but also require specialists able to make optimal, often non-standard decisions promptly, to act creatively and independently, employees with a higher level of spiritual and moral-ethical qualities participating actively in solving social problems of the population. Not only the development of business and largely company development, but the successes of democratic transformations in society depend on the effective work of managers. It is necessary that the specialist should correlate each of his decisions and necessary actions with traditions, human values and principles. It is extremely important that the manager should not be guided solely by his own interests or ambitions in his activity.

An important place in the formation of the personality of a modern specialist, his leadership qualities and skills to make socially responsible decisions belongs to education. In the first section of the National Doctrine concerning the Development of Education approved by the Decree of the President of Ukraine on April 17, 2002 (No. 347/2002), it was noted that "education is the basis of the development of personality, society, nation, state, the pledge of the future of Ukraine. It is a determining factor in the political, socio-economic, cultural and scientific life of society. Education reproduces and increases the intellectual, spiritual and economic potential of society. Education is a strategic resource for improving the well-being of people, ensuring national interests, strengthening the authority and competitiveness of the state on the international scene"[6, p.860].

Higher education is an important component in the educational system providing fundamental scientific, professional and practical training of students. It is an important link in the comprehensive development of the state and society.

The intellectual level of the person largely depends on the level of his education. Solely a specialist with a high intelligence, formed through education and science, culture and morals, can significantly affect the socio-economic and political situation in society.

The modern educational system should also take into account the need for the development of personal autonomy as the main link of professional self-realization of a specialist in the future. In the process of learning the personal autonomy, interrelated with personal qualities can be considered as the ability of the student to act as a subject of the learning process: to set the goal of activity independently; to plan his own actions; to choose the ways of the educational activity and the form of work; to carry out a reflection, self-control; to take full responsibility for the results of the training activities.
The quality of training, the harmonious combination of scientific and educational work, the development of leadership qualities, patriotism, professionalism, social responsibility and justice are very important tasks that are currently facing institutions of higher education in Ukraine. The educational process in higher education institution will be more effective if it is carried out through the active practical activity of students - the way of their social being by transforming the individual into a potential bearer of culture, a person who will be able to enrich the society. Rationally organized educational process contributes to the progress of personality and the accumulation of necessary professional knowledge and skills.

Odessa National Academy of Food Technologies occupies a special place among the leading modern institutions of higher education of Ukraine. ONAFT, whose history originates in October 1902, today is not only one of the oldest educational and scientific centers of Ukraine, but also a recognized leader in the training of masters, bachelors and junior specialists for the food and grain industry. It is one of the leading institutes in the country. It brings together about 40 branches. 116 years of successful development including the school of millers, the technical school, the institute, the State and $\mathrm{Na}$ tional Academy confirmed the correctness of the determined strategic directions of their activity. The academy is a member of 14 international organizations [12, p. 3]. Every year, modern educational research laboratories are created, dozens of textbooks and monographs are published, scientific and practical editions are published too $[5$, p. 3].

ONAFT is one of the most important scientific and educational centers, whose team is actively working to be among the leaders of educational space in the world. The Academy has positive results in providing its graduates with current professional experience, advanced knowledge and important skills.

The activity of the academy team is aimed at the large-scale implementation of the modern educational model of the best European universities, which contributes to the strengthening of the integration in the educational process, to widening of science and production and to improving of the practical orientation in the process of specialists training for the food industry.

The educational process and public activity of students play an important role in the formation of the modern specialist and his creative activity. The educational process at Odessa National Academy of Food Technologies allows the student to reveal its intellectual world and creative activities. Via the system of scientific, methodological and pedagogical approaches, the student can assimilate, multiply and use knowledge, skills and other competences to become a harmoniously developed personality, a future specialist.

The success of the production teams, enterprises, organizations depends on the professional activity of their specialists. The success of any company is a great and cohesive work of many participants, but the advanced positions occupy only those structures where managerial ideas and decisions are being introduced effectively. 
The manager holds a main position in the management system of the organization. An important role of the manager is determined by the fact that he is endowed with the authority to make decisions. As a rule, the manager is in charge of any situation in the company. Managerial skills connected with emotional intelligence, with the evolution of a team, with leadership qualities, allow managers to influence the progress and activity of the organization totally. The decision is considered to be successful provided that it is realized practically, effectively and on time.

The preparation of managers at Odessa National Academy of Food Technologies has long traditions and is carried out at the Faculty of Management, Marketing and Logistics (MML). The Faculty of Management, Marketing and Logistics, established in 2011 on the basis of the Faculty of Management and Marketing, originates from the engineering and economic faculty, founded in 1933 on the basis of Odessa mechanical and technological educational and production complex (today ONAFT). More than 1000 specialists of this specialty have graduated from the walls of the Academy for seven-year period. Many of them were appointed to the leading positions in Ukraine and other countries of the world.

The FMUC Faculty includes three departments: two graduating departments - a department of Management and logistics and a department of Marketing, Entrepreneurship and Trade. The Department of Sociology, Philosophy and Law is included too. The Faculty of Management, Marketing and Logistics numbers over 600 full-time and part-time students. More than 60 teachers work at the three departments, including six doctors of sciences and 30 candidates of sciences. The faculty trains bachelors and masters in the specialties of "Management", "Public Administration and Administration", "Marketing", "Entrepreneurship, Trade and Stock Exchange activity" [5, p. 236]. The educational process at the faculty is implemented within the frameworks of multiform integral system of organizational forms and methods of training. Studying of disciplines "Planning of the enterprise", "Strategic Planning", "Business Planning", "Social Responsibility", as well as conferences, trainings, master classes, round tables, business games are the effective forms of students' leadership qualities formation and their social responsibility development.

Traditionally, the most important form of education and upbringing of students is a lecture. The teachers of the faculty practice such lectures as the Theme-lecture, which highlights the specific topic of the curriculum on a particular discipline; The Review Lecture, which involves systematic analysis of the most important scientific problems of the course; The advisory lecture, complementing the material of the observation one, highlights the sections of the course that cause difficulties during the independent study; The Special lecture based on the material of the research work of the teacher beyond the curriculum, and others.

Lectures are organically related to practical classes. In practical classes, the teacher organizes detailed consideration of the individual theoretical foundations of the discipline dealing with students and forms the ability and skills of their practical application by individual execution of the relevant tasks. The classes are conducted in the laboratories equipped with the necessary apparatus for training. Lately, technical equipment has been purchased for more than 60 thousand UAH, which led to a significant completing of the methodology with teaching multimedia technique. Such approach allows lecturers to convey their ideas better and students to comprehend more relative information and advanced management experience.

One of the main types of practical classes is the seminars, in which the teacher organizes the discussion of students of the most complex issues. Such classes contribute to deep comprehension of the theoretical problems, the mastering of the scientific apparatus, the formation of their skills in the oratorical art, the ability to argue their judgments, to conduct a scientific polemic, to protect their own opinion. The practice of conducting classes at the advanced enterprises, such as "Mironivsky khlibopoduct", "Odesavinprom", "Nova poshta", "Agromarin", Odessa trade port "Yuzhny", Open Company "Odessa Korovai", "Vitmark Ukraine", "Savranska syrovarnia", "Somik" "Agrofirma khlibna nyva", "Pomaranch", "Ukrayinska alcoholna kompaniya Kristal", "Lukrou", "Shabo" and many others is widely used at MML faculty.

The special place in the structure of the educational process of ONAFT at the faculty of MML belongs to the consulting. Various forms of consultations - interviews individual or group interviews beyond curriculum are widely used by the teachers of the department.

Practical training of students is carried out through educational, production, research, and diploma practices. Practice provides a sequence and continuity of the formation of skills, professional competence of future specialists for the food industry. Practice contributes to the direct combination and implementation of theoretical knowledge received by students of ONAFT with their practical activities. This fact allows students to consolidate and deepen knowledge of the theory, as well as to acquire skills and knowledge necessary for the future work as the manager.

It is important to note that it is practical skills that help students to understand the peculiarities of their future profession, since it is the practice in the real company will create the most complete picture of their future professional activity. During the practice, students are offered to work, apply theoretical knowledge to practice, and also learn to act on the principle "here and now". Thus, making decisions, the student will be able to fully show his abilities and talents, as well as to learn to work in a team. The practice report is the principal document in which student will inform his results of practical using of theoretical knowledge.

The creative approach to the organization of the educational process at the Faculty of Management, Marketing and Logistics of ONAFT, students' participation in the students' self-government bodies of the Academy allow to train not only professional managers but also future leaders of the team. Nowadays, the problem of leadership is particularly relevant, since, the developing community needs leaders who will be able to combine 
people around them to achieve their goal and create favorable conditions for their further development. One of the significant definitions in this direction is the students' self-government at ONAFT. The purpose of students' self-government is to create conditions for self-realization of the individual personality and the formation of organizational skills, leadership qualities, responsibility for the result of work, etc. The activity of students' selfgovernment bodies is aimed at improving of the educational process, increasing its quality, ensuring the education of spirituality and culture of students, growth of social activity of student's youth [8].

The leader plays the main role in the joint activity organization of a team he belongs to and regulates interpersonal relations in it. The leader must form and unite the team, determine its purposes, put the necessary tasks before the staff, determine the means and identify the reserves to reach the goal, to ensure control of the implementation. Positive qualities of the leader should be the subject of respect for his environment.

The professionalism of the leader is also determined by his ability to ensure the conduct of socially responsible activity of the team. The social responsibility of business, entrepreneurial activity, the compliance with ethical norms and environmental protection are important and relevant business tasks facing the development of the society nowadays.

Social responsibility of business can be characterized as a voluntary contribution of the organization to the development of the society, socio-economic and ecological spheres. It aims at the evolution and high-quality improvement of these spheres, guarantees security and progress, ensures the coordination of the interests of the subjects involved in public relations and their management.

Social responsibility of business, compliance with ethical norms and environmental protection are not less important and relevant business tasks than the financial indicators of the organization activity or the system of remuneration of top managers, as corporate responsibility issue may also affect the business reputation and the cost of business as standard indicators of economic growth.

The modern higher school basing on humanistic training and education of highly skilled professionals should ensure socially responsible using of science, technology and culture achievements by all humanity in the interests of present and future generations.

Formation of social responsibility as one of the most important professional qualities of a specialist requires focused and differential work with all the students. Knowledge acquired in the course of students' training has special significance to be converted into conviction, to become a motive of behavior, to find its detection in practical activity. Social responsibility is logically considered as an integral quality of a person determining the behavior, the activity of the person on the basis of the awareness and the adoption of necessary dependence of this activity from the social obligations and values. Social responsibility is a component, system-forming factor of social maturity and its criterion.

Understanding of a special role in the activity in conditions of socio-economic transformations by business leaders, led to the emergence of the term "corporate social responsibility" at the end of the twentieth century, which became the most important component of the concept of sustainable development not only of business, but also of humanity as a whole.

Nowadays, the most common definition of the concept of "sustainable development" was proposed in the report of the Brundtland Commission ("BRUNDTLAND") "Our Common Future" in 1987. According to this report, "sustainable development" is such development that "satisfies the needs of the current generation and does not prevent the possibilities of future generations to meet their own needs". It foresees ensuring a high standard of living for the current and future generations. The generally accepted statement about the concept of sustainable development includes at least two important ideas:

- this development involves solving economic, social and environmental problems. The progress will be stable provided that the balance between various factors leading to general improving of overall standard of living is reached;

- the present generation has an obligation before future generations to leave them sufficient reserves of social, natural and economic resources so that they could provide themselves and next generations with adequate resources that will lead to a higher level of welfare in comparison with the one we have now [7, p. 40].

The competence of a specialist is an integrated professional-personal quality, necessary for the implementation of the activity. The essence of the professional competence is the readiness of a specialist to solve relevant and promising professional tasks, realizing the social significance and personal responsibility for the results of the activity, the need of continuous improvement and concentration on professional success.

Numerous rewards of the students at the Faculty of Management, Marketing and Logistics are the indicator of success of the implementation of the training strategy of the future manager, the leader of the team. Thus, the students of the faculty have been awarded seven times (including four awards for the first places) for five year participation in the International Students' Competition of advertising and PR-projects. Victories gained held in the International contest "Black Sea Science 2018" in the field of "Economics and Management", in the contest of Students' research papers "Innovative decisions in the economy in the opinion of young people" and many others [11].

The high level of education and formation of leadership qualities can be confirmed by successful and ambitious graduates of the faculty that have achieved significant success in their professional activities. 
Among them are: Dombrovska N. - General Director of LLC "Olir Rezorsiz", Selikhov S. - Director of LLC "Selkom Ltd", Volkov V. - Director of LLC "Trans oil Odessa", Cheglatonev V. - Head of the freight transportation department of "Zhulyany airport", Dyachenko A. Head of the regional management of "Privatbank", Moseev G. - Financial Director of CJSC "City Insurance Company", Kuzyak I. - Head of production of PJSC "Shabo", Serbin V. - Marketing Director of "Infomir", Yarovenko T. - Marketing Director of the GP "Grain Capital", Oliynyk O. - Director of the Computer School "Hillel" [3, p. 236].

Conclusions and prospects of the further investigations. According to the results of the study and analysis of the effectiveness of the organization of the educational process at the Faculty of Management, Marketing and Logistic, the authors consider that it is highly necessary to continue the education of leadership qualities and social responsibility of students. They also recommend paying more attention to the activity related to the evolution of the personality, development of leader- ship qualities, communicative and organizational abilities, namely:

- development of the national consciousness, spirituality, moral, artistic and esthetic, legal, labor, physical, ecological culture;

- identification of leaders among students of the Faculty of Management, Marketing and Logistics of Odessa National Academy of Food Technologies and involving them in active practical work;

- training of students to make decisions independently, defending their point of view, work in a team, take an active part in innovative projects;

- development of skills to work in a cohesive and single team.

The authors analyzed the basic approaches to education and development of students introduced in ONAFT. They came to the conclusion that their approaches correspond to goals of the modern educational system completely.

\section{References}

1. Hohulia, O. P. (2008). Sotsialna vidpovidalnist biznesu. Kyiv: Vydavnytstvo Natsionalnoho universytetu bioresursiv ta pryrodokorystuvannia Ukrainy.

2. Zatieishchykova, O. O. (2014). Etapy formuvannia stratehii sotsialnoi vidpovidalnosti. Biznes Inform,(2), 200-205.

3. Zinchenko, A. H. (2010). Korporatyvna sotsialna vidpovidalnist 2005-2010: Stan ta perspektyvy rozvytku. Kyiv: Farbovanyi lyst.

4. Kovalchuk, N. V. (2014). Ekonomichni aspekty priorytetiv intehratsii Ukrainy. Visnyk DDFA. Ekonomichni Nauky., (1), 81-88.

5. Kananykhina, O. M., Solovei, A. O., \& Biliavska, N. P. (2017). Odeska natsionalna akademiia kharchovykh tekhnolohii (B. V. Yehorov, Ed.). Odesa: Chornomor'ia.

6. Pro Natsionalnu doktrynu rozvytku osvity: Ukaz Prezydenta Ukrainy za stanom na 03.05.2002 r. (2002). Ofitsiinyi Visnyk Ukrainy, 1-11.

7. Okhrimenko, O. O., \& Ivanova, T. V. (2015). Sotsialna vidpovidalnist. Kyiv: Natsionalnyi tekhnichnyi universytet Ukrainy «Kyivskyi politekhnichnyi instytut».

8. Polozhennia pro studentske samovriaduvannia. (2014). Retrieved November 12, 2018, from https://www.studlife.onaft.edu.ua/images/student_council/stud_pologenie_3.pdf

9. Saprykina, M. A., Liashenko, O. M., \& Saiensus, M. A. (2011). Korporatyvna sotsialna vidpovidalnist: Modeli ta upravlinska praktyka. Kyiv: Farbovanyi lyst.

10. Sliusarenko, O. O. (2016). Poniattia «lider» i «liderstvo»v suchasnii naukovii literaturi. Naukovyi Visnyk Uzhhorodskoho Universytetu, (2 (39)), pedahohika. sotsialna robota, 244-246.

11. Tsikavi fakty pro fakultety ONAKhT. (2018). Tekhnoloh, (16), p. 2.

12. Kananykhina, O. M., Solonytska, I. V., \& Solovei, A. O. (2017). Shanuiemo tradytsii. Istoriia instytutu kharchovoi promyslovosti im. M. V. Lomonosova. Kharchova Nauka I Tekhnolohiia, (3), 3-16.

13. Anhielov, H. V. (2017). Pro perspektyvni napriamy rozvytku ekonomichnoi nauky v Odeskii natsionalnii akademii kharchovykh tekhnolohii: Istoriia i suchasnist. Ekonomika Kharchovoi Promyslovosti, 9(2), 81-87. doi:10.15673/fie.v9i2.647

14. Kalaman, O. B. (2016). Vazhlyvist samostiinoi roboty studenta. In Perspektyvy rozvytku naukovometodychnoho zabezpechennia dlia samostiinoho vyvchennia dystsyplin ta yikh okremykh rozdiliv (pp. 52-53). Odesa: ONAKhT. 
Каламан О.Б.

кандидат экономических наук, доцент кафедра менеджмента и логистики E-mail: kalaman.olga@gmail.com ORCID ID: 0000-0001-5586-7654

Соловей А.A.

кандидат исторических наук, доцент кафедра социологии, фрилософии и права E-mail: solovanatoly@gmail.com ORCID ID: 0000-0003-0047-0179
Кананыхина Е.H.

кандидат технических наук, доцент кафедра биохимии,микробиологии и фризиологии питания E-mail: k_elni@ukr.net

ORCID ID: 0000-0001-6291-7760

Безнис П.н. ассистент

кафедра иностранных языков

Одесская национальная академия пищевых технологий ул. Канатная, 112, г. Одесса, Украина, 65039

E-mail: polina11000@ gmail.com

\section{ФОРМИРОВАНИЕ ЛИДЕРСКИХ КАЧЕСТВ И СОЦИАЛЬНОЙ ОТВЕТСТВЕННОСТИ СОВРЕМЕННОГО МЕНЕДЖЕРА В ОДЕССКОЙ НАЦИОНАЛЬНОЙ АКАДЕМИИ ПИЩЕВЫХ ТЕХНОЛОГИЙ}

В статье представлено исследование о необходимости формирования у студентов лидерских способностей и их личной социальной ответственности, что позволит в будущем выпускникам овладеть умением работать в команде, быть эфффективным руководителем любого уровня на предприятии. Отмечено, что в последнее время вопрос лидерства, социальной ответственности личности в политической и экономической жизни общества, в предпринимательской и научной деятельности, приобретают все большую актуальность. Поэтому, в статье проведен анализ, определены перспективы развития лидерских качеств будущих менеджеров на примере организации этой работы на факультете менеджмента, маркетинга и логистики Одесской национальной академии пищевых технологий.

Показано, что состояние мирового хозяйства в современных условиях характеризуется активизацией рыночной экономики, информационным развитием общества, открытостью рынков, интенсификацией внедрения инновационных технологий и расширением общего уровня технологизации производства. Указано, что такие изменения требуют от работников не просто более высокого уровня профессиональной квалификации, способности оперативно принимать оптимальные, часто нестандартные решения, действовать творчески и самостоятельно, но также и более высокого уровня духовных и морально-этических качеств, активного участия в решении социальных проблем населения. От эффективной деятельности специалистов во многом зависит не только бизнес, развитие компании, а также успешность демократических преобразований в обществе. Поэтому в статье показано, что специалист должен соотносить каждое свое решение и действие с традициями, общечеловеческими ценностями и принципами, а не руководствовался в своей деятельности только собственными интересами или амбициями.

Анализ показал, что у студентов фракультета менеджмента, маркетинга и логистики достаточно развиты личностные качества, необходимые современному руководителю. В связи с этим в статье приведены показатели, в значительной мере характеризуют развитие лидерских качеств, социальной ответственности, коммуникативных и организаторских способностей студентов.

Ключевые слова: лидерство, лидерский потенциал, студенты, образование, менеджмент, социальная ответственность.

Каламан О.Б.

кандидат економічних наук, доцент кафедра менеджменту і логістики E-mail: kalaman.olga@ gmail.com ORCID ID: 0000-0001-5586-7654

Соловей А.O.

кандидат історичних наук, доцент кафедра соціології, фрілософії і права

E-mail: solovanatoly@gmail.com ORCID ID: 0000-0003-0047-0179
Кананихіна О.М.

кандидат технічних наук, доцент кафредра біохімії,мікробіології та фрізіології харчування E-mail:k_elni@ukr.net

ORCID ID: 0000-0001-6291-7760

Безніс П.М.

асистент

кафедра іноземних мов

Одеська національна академія харчових технологій вул. Канатна, 112, м. Одеса, Україна, 65039

E-mail: polina11000@ gmail.com

\section{ФОРМУВАННЯ ЛІДЕРСЬКИХ ЯКОСТЕЙ ТА СОЦІАЛЬНОЇ ВІДПОВІДАЛЬНОСТІ СУЧАСНОГО МЕНЕДЖЕРА В ОДЕСЬКІЙ НАЦІОНАЛЬНІЙ АКАДЕМІЇ ХАРЧОВИХ ТЕХНОЛОГІЙ}

У статті представлено дослідження необхідності формування у студентів лідерських здібностей і їхньої особистої соціальної відповідальності, що дозволить в майбутньому випускникам 
оволодіти вмінням працювати в команді, бути ефективним керівником підприємства будь-якого рівня. Відзначено, що останнім часом питання лідерства, соціальної відповідальності особистості в політичному та економічному житті суспільства, в підприємницькій та наукової діяльності, набувають все більшої актуальності. Тому, у статті проведено аналіз, визначено перспективи розвитку лідерських якостей майбутніх менеджерів, на прикладі організації цієї роботи на фракультеті Менеджменту, маркетингу і логістики Одеської національної академії харчових технологій.

Показано, що стан світового господарства в сучасних умовах характеризується активізацією ринкової економіки, інформаційним розвитком суспільства, відкритістю ринків, інтенсифікацією впровадження інноваційних технологій та розширенням загального рівня технологізації виробництва. Зазначено, що такі зміни вимагають від працівників не просто більш високого рівня професійної кваліфікації, здатності оперативно приймати оптимальні, часто нестандартні рішення, діяти творчо та самостійно, але також і більш високого рівня духовних і морально-етичних якостей, активної участі у вирішенні соціальних проблем населення. Від ефективної діяльності фахівців багато в чому залежить не тільки бізнес, розвиток компанії, а також успішність демократичних перетворень в суспільстві. Тому в статті показано, що фахівець має співвідносити кожне своє рішення та дію 3 традиціями, загальнолюдськими цінностями і принципами, а не керувався у своїй діяльності лише власними інтересами чи амбіціями.

Аналіз показав, що у студентів фракультету Менеджменту, маркетингу і логістики достатньо розвинені особистісні якості, необхідні сучасному керівникові. У зв'язку з цим в статті наведені показники, що в значній мірі характеризують розвиток лідерських якостей, соціальної відповідальності, комунікативних і організаторських здібностей студентів.

Ключові слова: лідерство, лідерський потенціал, студенти, освіта, менеджмент, соціальна відповідальність.

\section{Література}

1. Гогуля О. П. Соціальна відповідальність бізнесу. К.: Видавництво Національного університету біоресурсів та природокористування України, 2008. 79 с.

2. Затєйщикова О. О. Етапи формування стратегії соціальної відповідальності // Бізнес Інформ. 2014. №2. C. 200-205.

3. Зінченко А. Г. Корпоративна соціальна відповідальність 2005-2010: стан та перспективи розвитку. К.: Фарбований лист, 2010. 56 с.

4. Ковальчук Н. В. Економічні аспекти пріоритетів інтеграції України // Вісник ДДФА. Економічні науки. 2014. №1. С. 81-88.

5. Одеська національна академія харчових технологій / [О. М. Кананихіна, А. О. Соловей, Н. П. Білявська та ін.; за ред. проф. Б. В. Сгорова]. - Одеса: Чорномор'я, 2017. - 288 с.

6. Про Національну доктрину розвитку освіти: Указ Президента України за станом на 03.05.2002 p. / Офіційний Вісник України. 2002. 11 с.

7. Охріменко О.О., Іванова Т. В. Соціальна відповідальність: навч. посіб. К.: Національний технічний університет України «Київський політехнічний інститут», 2015. 180 с.

8. Положення про студентське самоврядування [Електронний ресурс] / OHAXT. Одеса, 2014. URL: https://www.studlife.onaft.edu.ua/images/student_council/stud_pologenie_3.pdf (дата звернення: 12.11.2018).

9. Саприкіна М. А., Ляшенко О. М., Саєнсус М. А. Корпоративна соціальна відповідальність: моделі та управлінська практика: посібник. К.: Фарбований лист, 2011. 480 с.

10. Слюсаренко О. О. Поняття «лідер» і «лідерство» в сучасній науковій літературі // Науковий вісник ужгородського університету. Сер. Педагогіка. Соціальна робота. Ужгород, 2016. №2 (39). С. 244-246.

11. Цікаві факти про факультети ОНАХТ // Технолог. 2018. (№16). С. 2.

12. Кананихіна О.М., Солоницька І.В., Соловей А.О. Шануємо традиції. Історія інституту харчової промисловості ім. М. В. Ломоносова // Харчова наука і технологія. 2017. №3. С. 3-16.

13. Про перспективні напрями розвитку економічної науки в Одеській національній академії харчових технологій: історія і сучасність / Г. В. Ангєлов та ін. // Економіка харчової промисловості. 2017. Т.9, вип.2. С. 81-87. DOI: 10.15673/fie.v9i2.647

14. Каламан О.Б.Важливість самостійної роботи студента // Перспективи розвитку науковометодичного забезпечення для самостійного вивчення дисциплін та їх окремих розділів: матеріали 47 наук.метод. конф., Одеса. 4-5 квітня 2016 р. / ОНАХТ. Одеса, 2016. С. 52-53.

Стаття надійшла 26.12.2018

Стаття прийнята до друку 9.01.2019 Доступно в мережі Internet 19.03.2019

Цитування згідно ДСТУ 8302:2015

Kalaman O., Kananykhina O., Solovey A., Beznis P. Formation of leadership qualities and social responsibility of the modern manager in Odessa national academy of food technologies // Food Industry Economics. 2019. Vol.11, Issue 1. P. 59-65;

doi: 10.15673/fie.v11i1.1295

Cite as APA style citation

Kalaman O., Kananykhina O., Solovey A., \& Beznis P. (2019). Formation of leadership qualities and social responsibility of the modern manager in Odessa national academy of food technologies. Food Industry Economics, 11(1), 59-65;

doi: 10.15673/fie.v11i1.1295 